\title{
UMA COLEÇÃO CONTEMPORÂNEA NA USP
}

O Museu de Arte Contemporânea (MAC) foi criado em 1963, quando a Universidade de São Paulo, na gestão do Reitor Ulhôa Cintra, recebeu de Francisco Matarazzo Sobrinho, então Presidente do Museu de Arte Moderna (MAM) de São Paulo, o acervo que constituía o MAM.

Nos documentos de transferência deste acervo para a USP, consta a data de 08 de fevereiro, mas o início das atividades do MAC se dá somente dois meses depois, no dia 08 de abril.

O Museu de Arte Contemporânea da USP tem como herança a história da constituição da primeira coleção especializada em arte do século XX, na América Latina.

Além desta coleção que se transferiu para a Universidade de São Paulo, Matarazzo e sua mulher, D. Yolanda, fizeram a doação de suas coleções particulares.

Na história de nosso Museu não houve nenhuma participação do Estado, nenhuma política de ação efetiva de teor público, embora se possa visualizar na experiência do Departamento de Cultura - criado em 1935, junto ao município de São Paulo, através do projeto intelectual de personalidades como Paulo Duarte, Mário de Andrade, Sérgio Milliet, entre outros - uma pri-

\section{A AUTORA}

\section{Lisbeth Rebollo Gonçalves}

Diretora do MAC-USP e professora doutora de História da Arte do Departamento de Comunicações e Artes da ECA-USP. meira tomada de consciência da necessidade de uma ação organizada voltada para a arte moderna. Pensava-se um modelo de museu que produzisse a formação e a informação atualizada do conhecimento artístico contemporâneo. Foi no espaço da crítica de arte veiculada por revistas especializadas $\mathrm{e}$ pelos jornais que tal discussão emergiu, ao mesmo tempo em que começava a se estruturar mais nitidamente a construção do pensamento sobre a arte brasileira.

Perdendo o Departamento de Cultura o vigor dos primeiros três anos de atividade, com a saída de Mário de Andrade da sua direção, as circunstâncias históricas canalizam, potencialmente, para o colecionismo privado, o poder para criar um museu como espaço social de difusão artística.

Nos anos 40, logo após a segunda grande guerra, ocorre o estímulo norte-americano através do exemplo bem sucedido do MOMA (Museu de Arte Moderna) de Nova York. Dá-se, inclusive, a doação, por parte de Nélson Rockfeller, de um núcleo inicial de dez obras internacionais dos artistas Alexander Calder, André Masson, Max Ernst, Fernand Léger, George Grosz, Marc Chagall, Robert Gwathmey, Jacob Lawrence, Arthur Osver e Everett Spruce.

\section{DESTAQUE PARA A PRODUÇÃO OCIDENTAL}

Como todo acervo museológico, o do MAC da USP se constrói dentro da realidade histórica. Portanto, seu perfil é circunstanciado por valores em torno dos quais fluem a 
mentalidade de nossa vida intelectual, de nosso processo de modernização social, das características de nossa modernidade.

$O$ perfil da coleção originária do MAC permite-nos situar a presença de um "padrão histórico" de produção e recepção da arte nitidamente delimitado e demarcado pela relação Europa-Brasil, nucleado em forma de aspectos ou de artistas dos principais movimentos da primeira metade do século. No âmbito de seu aspecto internacional, esta coleção reúne obras relevantes para conhecer as preocupações estéticas desta época. Há algumas "obras de ponta", como Boccioni, De Chirico e Modigliani, Max Bill, por exemplo. No âmbito de seu aspecto nacional, é constituído por significativas obras dos principais artistas que constroem a trajetória da produção plástica brasileira.

A característica básica deste acervo é destacar a produção ocidental demarcada pelos principais movimentos que eclodem na Europa em sua dialética com a experiência do País, mantendo a dinâmica da relação internacional versus nacional.

Nesta época, não há um contingente relativo à produção de arte latino-americana.

Num segundo momento, outro fator constitui-se em alavanca para a constituição do acervo, garantindo de alguma forma sua atualização em termos de contemporaneidade. Trata-se da ação institucional da Bienal de São Paulo que transfere para o acervo do MAC numerosas obras presentes em seus eventos.

Ao longo dos seus primeiros dez anos de existência, de 1951 a 1961, a Bienal de São Paulo é um evento internacional do MAM e, por seu intermédio, quer através dos prêmios de aquisição, quer por doações individuais dos artistas que a ela comparecem, a coleção se enriquece com a presença de nomes que se destacam no cenário artístico mundial. A partir desse momento, ocorre alguma absorção de latino-americanos na coleção do Museu, na medida em que estes artistas comparecem àquela exposição internacional.

O MAC herdou do MAM o desafio de responder à dinâmica viva da criação contemporânea. Ao longo de seus 31 anos de atividades na USP e pela interveniência de seus diretores, procura-se garantir esta dinâmica.

Nos primeiros anos, definiu-se uma política de aquisição e, apesar das escassas verbas, há uma dotação orçamentária específica para compra de obras. Depois, acrescem-se novas doações de artistas e ainda, em dimensão menor, ocorre a entrada de obras através da Bienal. Há também a doação da coleção Theón Spanudis, em 1979, mas não se pode dizer que existam condições ideais para firmar uma política dirigida de aquisição.

Nas atividades temporárias é que se dá o peso maior da presença crítica do Museu em torno da atualidade contemporânea. Há mostras coletivas de grande porte que põem o foco na Jovem Arte, as exposições de artistas que pesquisam linguagens emergentes ou exposições que recortam e confrontam -todas as tendências atuais contribuem para apontar as diferentes direções da produção plástica.

Integrado à USP, o MAC possui um privilégio: o de poder estar em interação viva com a pesquisa científica, tecnológica e cultural que se constrói na mais importante universidade brasileira.

Hoje, seu acervo possui 5362 obras entre óleos, desenhos, gravuras, esculturas, objetos e obras conceituais e oferece ao público inúmeras atividades dentro de sua função museológica.

O MAC possui, atualmente, duas sedes: uma na Cidade Universitária, à Rua da Reitoria 160 e 109A e outra, no Parque Ibirapuera, no terceiro andar do mesmo edifício da Bienal de São Paulo. 